The final version of this paper appeared in the Journal of Economic Issues, 2017, 51(4).

\title{
Modern Money Theory and Distributive Justice
}

\author{
Author: Justin P. Holt
}

Abstract: Modern money theory is a conjecture concerning fiscal spending and the nature of money. I show that modern money theory provides two interesting insights into distributive justice that have not been addressed in the recent Anglo-American distributive justice literature: (i) that the nature of a sovereign fiat currency allows for some distributive conflicts to be avoided; and (ii) that recent AngloAmerican distributive justice theories assume that the economy is at capacity. Based on this, I consider if the policy results of modern money theory can help foster a sense of justice.

Keywords: philosophy, modern money theory, welfare

JEL Classification Codes: A12, E12, I3

I argue that modern money theory can provide two interesting insights into distributive justice, which have not been addressed in the recent Anglo-American distributive justice literature: namely, (i) that the nature of a sovereign fiat currency allows for some distributive conflicts to be avoided; and (ii) that modern money theory provides the basis for the insight that recent Anglo-American distributive justice literature assumes that the economy under consideration is at capacity. I also consider if a sense of 
justice can be fostered by the policy results of modern money theory.

In order to argue for the above, I first provide an overview of modern money theory, in particular the nature of a sovereign fiat currency and the resulting fiscal operations of spending, taxation, and the issuance of state bonds. Second, I discuss the policy results of modern money theory: the provision of full employment through a job guarantee and the provision of public services (specifically public pensions). Third, I argue that, according to the insights of modern money theory, many distributive conflicts can be avoided and that traditional distributive justice theories assume that the economy of their models is always at full capacity. John Rawls (1999) maintains that it is desirable for a society to demonstrate a sense of justice, which is when a person's own conception of the good is reflected in the principles of a just and well-ordered society. Fourth, I speculate whether the results from modernmoney-theory policy may provide a mechanism for a society to develop a sense of justice. I offer my conclusions in the final section.

\section{Modern Money Theory}

The genesis, origins, logic, and implications modern money theory (MMT) have been reviewed by L. Randall Wray in several of his publications, which include two book-length treatments (Wray 1998, 2012). Numerous other explanations of MMT have been published by other authors. ${ }^{1}$ MMT is a recently coined term, but the principle conceptions of MMT can be found in the writings of Abba Lerner $(1943,1947,1951)$, who used the term functional finance. Recent MMT economists have developed Lerner's ideas in more nuanced ways. A short overview of the historical development of MMT's theory of money can be found in Wray (2014). In this section, I provide a brief treatment of MMT, first, by discussing sovereign fiat currency and, then, by reviewing the notion that fiat currency 
is backed up by a tax obligation. I also analyze the roll of spending, taxes, and bonds for a sovereign currency, while also exploring the concept of functional finance.

\section{Sovereign Fiat Currency}

MMT discusses many kinds of monetary arrangements, but it is mainly focused on sovereign fiat currency and its policy implications, especially the job guarantee. I discuss the policy implications of a sovereign fiat currency later in the article, but in this section I focus on MMT's argument about the nature and logic of sovereign currency. A sovereign currency is one issued by a state at the federal or central-government level. Examples of this kind of currency are the U.S. dollar, the Japanese yen, the British pound, the Chinese yuan, and the euro, to name a few. What defines a sovereign currency is that a state issues the currency and uses it for its official accounts (Wray 2012, 42). For example, the Federal government of the United States issues the dollar, through the state-created central bank, the Federal Reserve. The federal government of the United States is a currency issuer, not a currency user. It creates the currency for its official accounts. This currency is created mainly through the electronic crediting of private bank accounts, but currency can also be created by printing paper U.S. dollars or minting coins (though the U.S. Treasury). By contrast, all U.S. states are currency users. This means that the state of New Jersey does not create its own currency. Rather, New Jersey must obtain U.S. dollars through tax-, fee-, or fine collection or by taking out loans. Thus, while New Jersey uses U.S. dollars for its official accounts, it does not issue U.S. dollars.

The kind of sovereign currency, favored by MMT economists, is a fiat currency. A fiat currency is a currency that is non-convertible into a precious metal, any commodity, or a foreign currency (Wray 2012, 45 and 76). A fiat currency is only convertible into itself (Wray 2012, 46). A sovereign currency, which is created by a sovereign state, does not have to be a fiat currency. The sovereign currency could 
be redeemable for a commodity or a foreign currency. For example, if a sovereign currency is redeemable for gold, this means that the currency can be converted to gold on demand. The same would apply to a sovereign currency redeemable in a foreign currency.

One final aspect regarding sovereign fiat currency, which is important to MMT, is that a sovereign fiat currency should be an international floating currency. A floating currency is when its exchange rate is freely determined by international currency trades. This is in contrast to a pegged exchange rate, where the exchange rate of a currency is actively managed by the issuing nation. An example of a floating currency is one, like the U.S. dollar, whose international exchange rate is not managed by the federal government. The international value of the dollar is according to international currency trades. One example of a peg currency is the Chinese yuan, whose international exchange rate is managed by the Chinese government. The international value of the yuan is actively managed by the Chinese government to maintain — that, is peg — the yuan's value relative to other currencies. The important distinction between a floating sovereign fiat currency and a pegged sovereign fiat currency is that, according to MMT economists, a floated currency allows for greater policy space (Wray 2012, 151). In particular, a sovereign state has greater leeway in domestic goals, such as full employment, when its currency is floated. For example, a nation that deficit-spends to achieve full employment may have its currency depreciate. If this nation pegs it currency, the currency depreciation would jeopardize the intended exchanged rate. A nation with a pegged currency cannot deficit-spend as freely as it wishes, due to concerns about fluctuations in the international exchange rate. If a nation floats it currency, it has no intended exchange rate to defend, thus allowing more room for policy goals.

Taxes Drive Money 
If a sovereign fiat currency is only convertible into itself, why would people accept it as a payment? As stated above, a sovereign fiat currency is issued and not simply used by a sovereign nation. The currency is issued with no promise of convertibility into a commodity (gold) or a foreign currency. There is no governmental intention for the currency to be backed up by something other than itself. Why do people accept such a currency? MMT economists conjecture that sovereign fiat currency is accepted, at least by the domestic population of the issuing nation, because it is the money of account in which taxes are levied (Lerner 1947, 313; Mosler 1997-98, 170; Wray 2012, 48). Legal tender laws do not make a currency accepted by people (Wray 1998, 67). If the government of a nation can collect taxes (not all governments can do so), this creates a demand for the money of account in which taxes are levied.

Before the issuing of a currency, people have no need for the currency since their economic lives have proceeded without it. Wray documents that exchanges are possible without the printing or minting of state money to act as a means of exchange. Rather, tallies of exchanges, recorded on wood or clay were used to document credits and debits (Wray 1998, 40-42). For a state to intercede in the economic operations of a community and create a demand for its own money of account, a tax must be levied. When this tax obligation is only payable in a state-determined money of account, a demand for state money is created.

A nation that issues its own currency and can reliably collect taxes can purchase anything in its own currency of any amount (Wray 2012, 112). There are good reasons, as will be discussed below, for a sovereign nation not to buy anything it can. But, as long as the currency is needed for tax payments, people will accept it. Many people who are not subject to a tax obligation could still desire to obtain the money of account if the state money is regularly used in domestic exchanges. Foreigners may also wish to use the currency for trade or travel. 
Bonds and Taxes

A sovereign currency is a creation of a state. The existence of the currency - electronic, metal, or paper - is because the nation has issued it and not because the nation gains the currency through taxation or loans. The sovereign currency of a nation enters into use mainly through government spending. ${ }^{2}$ If a sovereign currency is spent into existence, this means that taxes or bond issuance are not necessary for the government to spend (Bell 2000; Mitchell and Mosler 2006; Ruml 1946a, 1946b). As discussed above, a tax levy creates a demand for a currency that the government then issues to allow people to meet their tax obligation.

If taxes and bonds do not finance government spending, then what is their purpose? I will discuss taxes first. Taxes have several purposes, with driving the currency being one of them. Beardsley Ruml $(1946 b, 268)$ notes that taxes can be used for inflation control, to maintain or achieve a level of income and wealth inequality chosen by a society, as a means to influence economic development and consumption ( $\sin$ taxes or fuel taxes), and to assign the cost of certain spending to those who receive the financed good (such as a highway tax or toll). In a nutshell, taxes are not used to finance spending. Rather, they are used to achieve the desired social goals chosen by society. I revisit this notion in the next section on functional finance.

If spending precedes taxation and spending does not require taxes, then one can see that bond sales by a state are not for the purpose of financing state spending. Rather, bond sales allow for the interest rate (the federal funds rate in the United States) to be maintained (Bell 2000, 612; Lerner 1951, 10 and 127; Wray 1998, 85). When a sovereign state spends its fiat money of account, the money supply increases. When this happens, all else being equal, the interest rate will decline. If a central bank wishes to maintain its interest rate target, it will have to remove some of this newly created money. The bank can 
do so by selling bonds (i.e., Treasury bonds in the United States). When a central bank sells a bond, the private sector exchanges money for the bond and the money supply contracts. The interest rate will thereby rise and the central bank can meet its interest rate target.

\section{Functional Finance}

Now that I have reviewed the major aspects of MMT, I will consider the theory of functional finance. Functional finance is the term Lerner used to describe the fiscal operations of a nation that uses a sovereign fiat currency. In this subsection, I introduce the notion of functional finance, discuss the principles of functional finance, and analyze the nature of debt and spending limits from a functional finance perspective.

Functional finance is the theory that the effects of taxing and spending are the important results of a state's fiscal position and not the size of the deficit or the debt (Lerner 1943, 42). Lerner defined functional finance as follows:

The central idea is that government fiscal policy, its spending and taxing, its borrowing and repayment of loans, its issue of new money and its withdrawal of money, shall all be undertaken with an eye only to the results of these actions on the economy and not to any established traditional doctrine about what is sound or unsound. This principle of judging only by effects has been applied in many other fields of human activity, where it is known as the method of science as opposed to scholasticism. The principle of judging fiscal measures by the way they work or function in the economy we may call Functional Finance. (Lerner 1943, 39) 
Lerner contrasted functional finance with a competing vision called sound finance. Wray $(2012,194)$ describes sound finance as "the belief that government ought to run its finances as if it were like a household or a firm." Thus, sound finance considers a sovereign government to be a currency user and not a currency issuer. A currency user must borrow, tax, or earn (like a euro nation, a U.S. state, or a person) to spend. As discussed above, a sovereign nation that issues its own fiat currency does not have to borrow or tax to spend. If this is the case, then a nation's deficit, debt, or spending is neither sound nor unsound. The effects of spending may be inflationary or deflationary, but the size of a given nation's debt, when it is denominated in its own issued currency, is not itself a point of concern. (I revisit spending limits below.)

Lerner characterized functional finance as having two laws or principles:

The first financial responsibility of the government (since nobody else can undertake that responsibility) is to keep the total rate of spending in the country on goods and services neither greater nor less than that rate which at the current prices would buy all the goods that it is possible to produce. (Lerner 1943, 39)

The second law of Functional Finance is that the government should borrow money only if it is desirable that the public should have less money and more government bonds, for these are the effects of government borrowing. (Lerner 1943, 40)

These laws of functional finance result in maintaining demand at the level of production capacity, neither higher nor lower, and bond issues are to maintain the interest rate and for inflation control. This 
means that part of the federal government's public purpose is to maintain full employment and price stability. By contrast, the public purpose is not to maintain the levels of the deficit or the debt at any particular amount or percentage, which would be a sound finance position.

If the goal of a sovereign government's fiscal and monetary position is not to achieve a sound level of the deficit or the debt, then is there any spending limit? Wray $(2012,70)$ finds that too much spending can be inflationary, but that a nation spending in its own sovereign fiat currency has no limit to what it can spend. Lerner noted: "An interesting, and to many a shocking, corollary is that taxing is never to be undertaken merely because the government needs to make money payments. According to the principles of Functional Finance, taxation must be judged only by its effects" (Lerner 1943, 40). ${ }^{3}$

Taxes should be levied to meet the public purpose of full employment and price stability, not to pay for spending. Thus, all else being equal, taxes should be raised to control inflation and lowered to allow for full employment. These are the effects of taxes and other goals, such as deficit reduction, may be contrary to the public purpose. Spending, including deficit spending, which exceeds the capacity of a nation to "buy all the goods that it is possible to produce" should be reduced since such conditions are inflationary.

\section{Policy Results of MMT}

MMT economists are interested in the policy results of a sovereign fiat currency and the principles of functional finance. As discussed above, a nation that issues its own currency does not have to finance its spending via taxation or bond issues. This expands the range of fiscal policy beyond the usual political problems of tax revolts and interest burdens. I discuss these important results of MMT for distributive justice later, but two policy results, which are of great interest to MMT authors, I will 
address in this section: namely, the job guarantee and the public funding of pensions.

\section{Job Guarantee}

A job guarantee is the provision of employment for all who desire it for an indefinite period. Individuals could be employed directly by a federal/central government, state government, local government, or non-profits. The wages of all job guarantee participants would be paid by the federal government with sovereign fiat currency. Advocates maintain that a job guarantee would provide full employment, price stability, increase the supply of labor, and reduce poverty. ${ }^{4}$ I address all of these claims in turn.

MMT authors have shown that a capitalist economy does not tend toward full employment (Mitchell and Muysken 2008, ch. 7; Wray 2007). Even when the economy does achieve what would normally be considered full employment, there are certain demographic groups who suffer from involuntary unemployment (Pigeon and Wray 1998). In addition, the ordinarily understood Keynesian's stimulus spending will not achieve sustainable full employment on its own (Tcherneva 2013). Because of these inadequacies in achieving demand effective enough and focused enough to reach real full employment through standard policy operations, MMT economists have recommended that the sovereign spending power of the state as an issuer of fiat currency should be utilized to fulfill this goal. Since the issuer of a sovereign fiat currency can purchase any good or service for sale in its currency, all involuntarily unemployed people can be provided with work at any time.

Price stability was an original goal of Lerner's theory of functional finance. MMT economists argue that a job guarantee can provide both full employment and price stability (Wray 2012, 222). A job guarantee acts as a price anchor for the sovereign currency since people are hired at a fixed price. 
Instead of the state paying market prices for labor, the job guarantee will offer work at a set wage. ${ }^{5}$ The job guarantee is what William Mitchell (1998) calls a buffer stock of labor. A buffer stock is a publicly maintained inventory of a commodity. There is a set price for buying and selling the commodity and any offer to buy or sell is met. The price of the buffered stock commodity becomes stabilized around the set price. ${ }^{6}$ Mitchell conjectures that a buffer stock of labor can be maintained via the pool of the unemployed. Due to the significant social losses associated with unemployment, a more humane buffer stock mechanism for establishing price stability would be the job guarantee. A job guarantee would operate like any buffer stock program. A set wage for work would be established and all people willing to work for this wage would receive employment. If the non-job guarantee sector (public and private) desired more labor, then they could entice workers from the job guarantee with more desirable wages and/or work.

Since the wage for job guarantee work is set, there is no tendency for wages to be bid up as employers compete for workers. Also, the supply of desirable workers has been increased by the job guarantee. Many employers do not wish to hire people who are unemployed. When an economic expansion gains momentum, firms bid up the wages of the currently employed. A job guarantee expands the set of employed workers. Thus, when employers wish to hire people with work experience, they can hire people out of the job guarantee without bidding up the cost of labor.

Minsky was an advocate of the job guarantee during the rise of the War on Poverty. He found that a policy focusing on training, general fiscal spending, and tax cuts would not eliminate poverty on its own (Minsky 2013, 19). He also found that rising employment significantly reduced the poverty rate (Minsky 2013, 63). Thus, any anti-poverty program, which did not achieve real full employment, could not significantly reduce poverty. The lack of sufficient work opportunities is demonstrated by the lower annual hours worked in 2007 by the bottom income quintile of working age households (1,880 hours) 
compared to all working age households (3314 hours) (Mishel et al. 2012, 436, Table 7.2). Also, there is a large number of workers who make poverty-level wages — 28 percent in 2011 (Mishel et al. 2012, 432). A job guarantee could provide sufficient hours, wages, and other services to substantially reduce

the poverty rate. ${ }^{7}$ The job guarantee wage would become the de facto minimum wage.

\section{Public Pensions}

MMT economists have a general interest in the funding of public services. They have paid particular attention to publicly funded pensions (Mitchell and Mosler 2006; Papadimitriou and Wray 1999). According to the principles of MMT, when a sovereign state's spending is not financed through taxation or bond issues, the problems of a shortfall in Social Security funding takes on a new light (SSA 2011, 46-62). If a nation can afford any good or service denominated in its own issued fiat currency, then, from a financial perspective, there is not a funding shortage for public pensions (Mitchell and Mosler 2006, 164).

The real issue, according to MMT authors, is the availability of real resources for the care of dependents — whether children, the disabled, or the aged. "We conclude that in a fully employed economy, the intergenerational spending decisions come down to political choices sometimes constrained by real resource availability, but never constrained by monetary issues, either now or in the future" (Mitchell and Mosler 2006, 161). Since a government is never revenue-constrained, there is no reason to save revenue for future projects. In addition, taxation is not for funding current spending. Thus, increased spending in the future, on pensions or any other project, does not merit an increasing tax burden today (Mitchell and Mosler 2006, 167). Instead, accruing a government budget surplus would drain income from the private sector and slow growth, making the buildup of real assets for 
private individuals, including an educated work force, more difficult to obtain (Wray 1998, 157-158).

Dealing with increasing dependency ratios of children and the aged will require real assets to meet their needs. This demand for real assets can best be met through sustained full employment (Mitchell and Mosler 2006, 162). The provisioning of public pensions, and any public provided goods or services, is not a spending issue. Rather, it is an issue of a sufficient supply of real assets.

\section{The Immediate Impact of MMT on Distributive Justice}

Thus far, I have presented the major claims, recommendations, and policy results of MMT. In this section, I will consider their immediate impact on issues of distributive justice. The common goals of the distributive justice literature are not only the meeting of people's basic biological and social needs, but also to allow people to participate in their society as political, social, and economic equals. ${ }^{8}$ What exactly these needs are and what constitutes equality are matters of great dispute. Economics and contemporary distributive justice are both "children" of the moral philosophy of the Enlightenment, so there should be no surprise that MMT authors say something of interest to their sister discipline. In this section, I will address two immediate impacts: (i) the possibility that some of the minimal goals of distributive justice can be achieved without the usual distributive conflict; and (ii) a review of the insight, based on MMT, that contemporary distributive justice assumes a full capacity economy in its theories.

\section{Sidestepping Distributive Conflict}

The standard policy recommendations of MMT authors are of the type that would lead to the fulfilling 
of basic biological needs and a situation where there is a tendency to reduce inequalities of a social and economic kind. In addition, there is not an overture to the strict equalization in these matters, which is more explicit in the work of John Rawls, G.A. Cohen, John Roemer, Paul Gomberg, Elizabeth Anderson, and Ronald Dworkin. In particular, if a job guarantee did reduce poverty of those who can work, and such a program built and provided new goods and services for the community as a whole, then there would seemingly be a reduction in economic and social inequality. Most obviously, there would be a movement of those with the lowest incomes upward due to increased money income and the in-kind services provided through the job guarantee. As noted by Dean Baker and Jared Bernstein (2013, 13-16), improvement in the unemployment rate disproportionately increases the wages earned and the hours worked for those in the lowest income quartile. Similar results could be expected for others with more substantial pension payments and the supporting infrastructure and services provided by job guarantee workers. Thus, some of the goals typical in the distributive justice literature are met by MMT policy recommendations.

As I previously discussed, a nation that issues its own fiat currency spends it into circulation. Spending is not financed through taxation, borrowing, or the seizure of real assets. When a nation spends its currency of issue, it does not subtract financial wealth from the private sector, but it adds to it through deficit spending (Wray 2012, 120). Furthermore, state spending can facilitate the creation of real wealth for use by the private sector. The state only removes financial wealth from the private sector by running a budget surplus (Wray 1998, 157).

The upshot of this theory regarding government deficit spending is that new assets are created without the redistribution of wealth ex ante. This means that a nation can create jobs and public services for its population without taxing beforehand. Thus, some of the minimal traditional goals of distributive justice can be obtained without the usually required conditions of justice, such as John Rawls's a sense 
of justice or G.A. Cohen's community ethos (which merit compliance with Rawls's difference principle or Cohen's socialist egalitarianism, both of which can manifest as redistributive taxation).

For example, the job guarantee is financed by money creation, according to MMT. The state will spend this money on wages and supply, usually purchasing the supply from the private sector. The result will be an increase in financial wealth for the private sector directly through the spending of the job guarantee and the ensuing multiplier effects. The general populace will also enjoy an in-kind increase in well-being from the goods and services provided by job guarantee workers. No financial wealth was taxed to pay for the newly created goods and services. The private sector receives net financial and real benefits. If taxes are to be levied they would be for inflation control, but this would not always be necessary. ${ }^{9}$

This is an important and interesting result since two of the main purposes of the distributive justice literature are to provide arguments for (and against) redistribution and social minimums in money income and in-kind goods and services. MMT principles show that full employment and net goods and services creation for the benefit of all do not require redistribution for their financing. The distributive conflict is not mediated by moral argumentation, but rather it is avoided by the spending powers of a sovereign issued currency.

\section{Capacity Assumptions}

The MMT research on the demand-constrained nature of modern capitalist economies brings to light the assumptions of distributive-justice authors that the economies of their theories are operating at full capacity. William Mitchell and Joan Muysken (2008, ch. 7) marshal data to show that capitalist economies usually operate below capacity. Furthermore, William Mitchell and Martin Watts (2004) 
criticize the standard assumption of a full capacity economy in the work of Philippe Van Parijs.

Rawls does have an overture to demand management within his theory (Rawls 1999, 244). The general outlook of Rawls's concept of distribution is that the gains produced within a society are due to those with the greatest advantages and are not achieved by using the productive potential of the marginalized, the unemployed, and the underemployed. Redistribution, via the difference principle, is necessary for society in general to enjoy the riches produced by high fliers. In one of its more final forms, the difference principle states that "social and economic inequalities are to be arranged so that they are ... to the greatest benefit of the least advantaged" (Rawls 1999, 266). Rawls also comments on the need for equality to preserve taxation (Rawls 1999, xv and 245). He states that society cannot increase the well-being of the least advantaged without redistribution. This means that society is operating at full capacity and resources cannot easily be created, so they must be moved. ${ }^{10}$

In his final great work, Rescuing Justice and Equality, Cohen (2008) gives considerable attention to arguments that would support taxation of those with high earnings in order to increase the well-being of the worst off. There is no discussion of increasing the well-being of the worst off through activating unused capacity. Rather, in Cohen's theory, when the poor go without, it is because the rich are using the resources. In addition, in one version of the argument, Cohen discusses possible Pareto-superior moves (Cohen 2008, ch. 2). In order to discuss an outcome as Pareto-optimal, there cannot be any undistributed resources and thus the economy is operating at full capacity in Cohen's distributive theories.

Both Rawls and Cohen assume not only that the economy of their theories is operating at full capacity, but also that new goods and services could not be created. This may be the case when all capital goods and labor are fully employed, but in the cases where there are constraints on the capacity of capital goods - as authors of underemployed labor find - job-guarantee workers could produce the needed 
capacity by themselves (Nell and Argyrous 2013, 150; Mitchel and Watts 2013, 10). In these circumstances, taxation for inflation control may be required since job-guarantee workers would purchase much of what they need for subsistence from the existing sectors, which are at capacity. The upshot is that, even when there are capacity constraints on capital goods, many of the minimal goals of the distributive justice literature can still be achieved.

Before moving on to other concerns, including the possible necessity of redistribution, I will comment on the wide range of real situations to which the insights of MMT would apply. Since mature capitalist economies tend toward excess capacity and involuntary unemployment, there are many occasions for deficit spending, without accompanying redistributive taxation, to achieve full employment and the improvement of material well-being. The situations where the distributive justice literature may apply are rare since the conditions of full-capacity utilization and voluntary unemployment rarely occur. That does not mean that the literature conclusions are without merit, as I discuss in the final section of this article.

\section{When to Redistribute?}

If taxes are not used to finance sovereign state spending (but rather to control inflation and to create demand for the money of account), and if full employment, poverty eradication, and increased publicservice provision do not require redistributive taxation, is there any need for redistribution?

Additionally, if a nation, issuing its own fiat currency, can afford anything for sale in its own currency, is there any need for redistributive taxation? A currency-issuing nation does not need to obtain currency, and thus many of its policy goals can be achieved by purchasing the resources to meet the needs of its populace. Redistribution is not necessary if people's needs and rights can be met through spending and public-asset creation. 
The policy goals that cannot be achieved through spending are of two types: (i) regulation and (ii) control of real assets. Regulation may be required to protect certain rights that could be supported by income but are not fulfilled by income. Two examples of these kinds of rights are the worth of liberty and equality of opportunity. Even if people had equal incomes, they may not be able to express their liberty equally or be considered on equal footing with others. In addition, some rights, such as workplace democracy or economic democracy, may be frustrated by private property rights. The fulfillment of these rights may require the redistribution of real assets to allow for democratic control of the economy.

\section{A Just Society and MMT}

As I have shown so far, MMT allows for many of the basic traditional goals of distributive justice to be fulfilled, while avoiding some distributive conflicts. Avoidance of these distributive conflicts is due to the ability of a sovereign nation to issue its own currency and the consideration that capitalist economies usually operate at less than full capacity. This means that full employment, poverty eradication, and public provisioning do not have to be financed through redistributive taxation. Beyond the interesting insights that MMT provides into distributive problems, there is the additional — and perhaps more important — question of whether MMT can shed any light on the development of a sense of justice. In the subsection that follows, I review Rawls's conception of a sense of justice and show that MMT's policy results may help develop a sense of justice.

The Sense of Justice in Rawls's Work

In the latter sections of $A$ Theory of Justice, Rawls (1999, 414 and 500) attempts to identify the 
conditions that would assist a person in building a sentiment of allegiance to his/her society beyond the satisfaction of his/her self-interest. Rawls call this sentiment a sense of justice. A person with a sense of justice considers the correct functioning of a well-ordered society to be commensurate with his/her own conception of the good. This means that a person's own rational plan of life and the just functioning of society are one and the same thing: "The desire to act justly and the desire to express our nature as free moral persons turn out to specify what is practically speaking the same desire" (Rawls 1999, 501). Rawls's (1999, 11-12) determines what is just according to what would be selected in the fair and unbiased situation of the original position under the veil of ignorance. The development of an individual's personal adherence to principles of justice is a separate issue related to a person's socialpsychological development. In short, the determination of justice and the development of one's conception of the right and good, which would be in conformity with justice, are not the same activity. Rawls provides an outline of a person's moral development according to a social-psychological theory of need satisfaction. There are three stages to the moral development of a person, which Rawls calls psychological laws. The first stage is the morality of authority, where a child develops the capacity to understand the moral transgression of commands and the expectations of their parents. The second stage is the morality of association, where a person understands their role (moral and practical) in the various associations to which they belong. The final stage is the morality of principles, where a person acts according to the principles of justice and no longer according to authority or to the expectations of their place in society (Rawls 1999, 405-419). I am concerned with only the last two stages in this article.

Rawls describes the morality of association in the following way:

As individuals enter the association one by one over a period of time, or group by group 
(suitably limited in size), they acquire these attachments when others of longer standing membership do their part and live up to the ideas of their station. Thus if those engaged in a system of social cooperation regularly act with evident intention to uphold its just (or fair) rules, bonds of friendship and mutual trust tend to develop among them, thereby holding them ever more securely to the scheme. (Rawls 1999, 411-412)

Since the proper operating of these associations allow for a person to satisfy their conception of the good, people develop a desire for their continuation (Rawls 1999, 412-413). The morality of association provides a process of social inertia in the development of sentiments for the institutions that structure the lives of people within a nation. The converse of this stage is when people are unable to develop their conception of the good in association with others and the operations in which they cooperate (if they do at all) do not uphold fair and just rules. If this is the case, people will not develop a morality of association where feelings of friendship and a desire to continue these activities are fostered. $^{11}$

If people do develop a morality of association, then Rawls conjectures they could develop the moral desire for the continuation of their society's institutions, as opposed to simply the self-interested desire which properly functioning associations foster. To this effect, Rawls states:

This [third psychological] law states that once the attitudes of love and trust, and of friendly feeling and mutual confidence, have been generated in accordance with the two preceding psychological laws, then the recognition that we and those for whom we care are the beneficiaries of an established and enduring just institution tends to engender in us the 
corresponding sense of justice. We develop a desire to apply and to act upon the principles of justice once we realize how social arrangements answering to them have promoted our good and that of those with who we are affiliated. In due course we come to appreciate the ideal of just human cooperation. (Rawls 1999, 414-415)

This third stage of moral development - the morality of principles — occurs when people, who live within fair societies that provide reasonable conditions for success for oneself and one's friends, develop a moral attachment to their society. This moral attachment entails the assumption that one would desire just outcomes that are not always to one's advantage (only). This desire is the development of a sense of justice: "[T]he sentiment of justice is not a different desire from that to act on principles that rational individuals would consent to in an initial situation which gives everyone equal representation as a moral person" (Rawls 1999, 418). A key condition of acting as a moral person is not utilizing one's advantages to coerce others to accept institutional conditions that are crafted to one's greater benefit. One seeks mutual advantage as a moral person, not as a self-interest-maximizing individual (Rawls 1999, 11-14).

\section{MMT and a Sense of Justice}

As I noted earlier, the determination of the principles of justice is an activity separate from the development of a sense of justice. This is not a problem in the presentation of Rawls's theory, but it is a problem in the development of a just society. Rawls provides the goal for people's social actions, but he does not provide a means for the fostering of the sentiments that would help construct a well-ordered society. As I argue, the policy results of MMT — full employment and poverty eradication, while 
avoiding distributive conflict - provide a possible means to transition from a society without a widespread sense of justice (i.e., one that lacks the institutions to foster the sentiment) to a society that has the institutions to do so.

The development of a sense of justice requires that a well-functioning society exists. People must develop a morality of association from fair and personally beneficial operations, in which they participate in order for them to develop a morality of principles. Within a less than just society, however, it is common for people to utilize their natural, family, economic, and social advantages to extract outcomes that are personally advantageous, but not mutually beneficial. In the absence of institutions to ensure the building of fellow-feeling, it appears unlikely that individuals would be willing to give up their advantages to construct such institutions. According to the principles of MMT, a nation that issues its own fiat currency has the ability to spend as much as needed to create such institutions, without having to redistribute from the advantaged to the disadvantaged.

The use of deficit-financed spending can produce a set of institutions that would develop the sentiment of the morality of association. If a job-guarantee achieves full employment, while providing goods and services to all members of society, then this sentiment could be fostered. Such a program would provide gains to all, without asking the advantaged members of society to give up their privileged position. Even though the advantaged are not taxed, they still receive the benefits of full employment and public provisioning through the multiplier effect, the direct enjoyment of public provisioning, the human capital improvement of the program participants, and the positive externalities of crime reduction, health improvement, and educational attainment. ${ }^{12}$ Through the achievement of mutual advantage, this program would foster fellow-feeling among and between the program participants and the program beneficiaries. Such a situation, I hope, would lay the foundation for the development of a sense of justice and hence the possibility for people to act as moral persons and not as an individual 
maximizers. $^{13}$

\section{Conclusion}

I have shown that MMT offers unique and interesting insights into the typical problems of distributive justice. However, I only consider the possibility for achieving many of the goals endorsed by the distributive justice literature theoretically here. The actual implementation of the policy results of MMT must weather the winds of various political interests. In particular, improving the position of the members of society who are the worst off can prove to be a fearful event for those who enjoy the (real or psychological) splendor of mature capitalism. In actuality, these beneficiaries have little to fear from programs of full employment and poverty eradication. Indeed, many would benefit financially and in real-assets accumulation. Nonetheless, the current political climate in advanced industrialized nations is one of distributive conflict, and the perception is that this conflict is of a zero-sum nature. If this is the dominant outlook, then people assume that the gains of others will be a loss to oneself. These are conditions that produce feelings of spite among those who are the best off, and additionally fuel their perception that all attempts to rectify unjust situations are driven by envy. I have attempted to show that many distributive problems could be rectified through the net creation of new assets at little-to-no expense (financial or real) for those who benefit greatly within the current arrangements. This does not mean that reasonable and mutually beneficial action will be taken.

\section{Footnotes}

${ }^{1}$ Stephanie Bell (2000), Mathew Forstater (1999), Fadhel Kaboub (2013), Warren Mosler (19971998), and William Mitchell and Joan Muysken (2008).

${ }^{2}$ A sovereign currency could be loaned into existence, such as when firms borrow at the Federal- 
Reserve discount window.

${ }^{3}$ Beardsley Ruml (1946a, 36) held a similar position: "All federal taxes must meet the test of public policy and practical effect. The public purpose which is served should never be obscured in a tax program under the mask of raising revenue."

4 The job guarantee is widely discussed by MMT authors, I will note the reasons why shortly. L. Randall Wray $(1999,2012)$ discusses the policy in both of his books on MMT. His views can also be found in several articles (e.g., Tcherneva and Wray 2005; Wray and Forstater 2004). William Mitchell also has several lengthy treatments (the two notable ones being Mitchell and Muysken 2008; Mitchell and Watts 2004). Michael J. Murray and Mathew Forstater (2013) edit a volume of articles on the topic of job guarantee. Harvey provides a thorough book length treatment of the job guarantee (1989). See also: (Mosler 1997-1998; Kaboub 2013; Forstater 1999; Minsky 2013).

5 Philip Harvey $(2013,45)$ recommends that the wages offered by a job guarantee be comparable to market rates.

${ }^{6}$ L. Randall Wray $(2012,226)$ notes that there would be a one-time increase in wages and prices when the job guarantee is introduced.

${ }^{7}$ William Mitchell and Martin Watts $(2004,7)$ suggest that job-guarantee workers could have their wages supplemented by additional social services at "adequate levels of public education, health, child care, and access to legal aid."

8 These goals are explicitly part of the distributive justice systems of John Rawls (1993, 1999), G.A. Cohen (2008), Ronald Dworkin (1981), John Roemer (1988), Amartya Sen (1992, 1999), Michael J. Sandel (2012), Elizabeth Anderson (2010), and Paul Gomberg (2007). Even in the work of Robert Nozick (1974), who is a distinctive dissenting voice, one could find overtures to these kinds of equality. 
Nozick (1974) relies on market transactions to achieve non-coercive outcomes and the preservation of a kind of equality of opportunity (on the latter point, see Nozick's comments on "catastrophe" [1974, $180])$.

${ }^{9}$ Hyman Minsky (2013) provides an outline for a similar program, having in mind the political difficulty of transfers to reduce inequality. He advocates a public employment program where the participants would receive much of their wage from the public goods they create $(2013,46)$.

${ }^{10}$ Or, really, they cannot be created from Rawls's perspective. In what follows, I show that MMT authors have a more nuanced outlook concerning capacity constraints.

${ }^{11}$ Ervin Staub (2004) presents a theory of such a negative satisfaction of social psychological needs.

12 The terminology I use in this article is different from that used by C.E. Ayres (1961). In particular the term "institution" as used in this paper to applies to technological and ceremonial functions (Ayres 1978, xv-xvii and 99). Thus, a direct comparison with Ayers is difficult in the space provided. Nonetheless, there is a strong overlap between Ayres's notion of the technological continuum as the means and end of the development of abundance, freedom, and equality and the use of MMT to provide for both full employment and a sense of justice (Ayres 1961).

${ }^{13}$ James Galbraith (2013) discusses the increase of fraud and decrease of trustworthiness as part of the third crisis of economics. If fraud is necessary to maintain profitability, a shift in the mode of accumulation is required to reestablish profitability and trustworthiness. Such a shift requires an economic and social action similar to my argument in this article. 


\section{References}

Anderson, Elizabeth. "The Fundamental Disagreement between Luck Egalitarians and Relational Egalitarians." Canadian Journal of Philosophy 40, Supplement 1 (2010): 1-23.

Ayres, Clarence E. Toward a Reasonable Society: The Values of Industrial Civilization. Austin, TX: University of Texas Press, 1961.

- The Theory of Economic Progress: A Study of the Fundamentals of Economic Development and Cultural Change. Third edition. Kalamazoo, MI: Western Michigan University, 1978.

Baker, Dean and Jared Bernstein. Getting Back to Full Employment: A Better Bargain for Working People. Washington, D.C.: Center for Economic and Policy Research, 2013.

Bell, Stephanie. “Do Taxes and Bonds Finance Government Spending?” Journal of Economic Issues 34, 3 (2000): 603-620.

Cohen, G.A. Rescuing Justice and Equality. Cambridge, MA: Harvard University Press, 2008.

Dworkin, Ronald. "What Is Equality? Part 2: Equality of Resources.” Philosophy and Public Affairs 10, 4 (1981): 283-345.

Forstater, Mathew. "Functional Finance and Full Employment: Lessons from Lerner for Today." Journal of Economic Issues 33, 2 (1999): 475-482.

Galbraith, James. “The Third Crisis of Economics.” Journal of Economic Issues 47, 2 (2013): 311-322.

Gomberg, Paul. How to Make Opportunity Equal: Race and Contributive Justice. Malden, MA: Blackwell Publishing, 2007.

Harvey, Philip. Securing the Right to Employment: Social Welfare Policy and the Unemployed in the United States. Princeton, NJ: Princeton University Press, 1989. 
—_ "Wage Policies and Funding Strategies for Job Guarantee Programs." In The Job Guarantee: Toward True Full Employment, edited by Michael J. Murray and Mathew Forstater, pp. 39-58. New York, NY: Palgrave Macmillan, 2013.

Kaboub, Fadhel. "The Fiscal Cliff Mythology and the Full Employment Alternative: An Affordable and Productive Plan.” Review of Radical Political Economics 45, 3 (2013): 305-314.

Lerner, Abba. "Functional Finance and the Federal Debt." Social Research 10, 1 (1943): 38-51.

—. "Money as a Creature of the State." American Economic Review 37, 2 (1947): 312- 317.

—. Economics of Employment. New York, NY: McGraw Hill, 1951.

Minsky, Hyman P. Ending Poverty: Jobs, not Welfare. Annandale-on-Hudson, NY: Levy Economics Institute, 2013.

Mishel, Lawrence, Josh Bivens, Elise Gould and Heidi Shierholz. The State of Working America, Twelfth edition. Ithaca, NY: Cornell University Press, 2012

Mitchell, William. “The Buffer Stock Employment Model and the NAIRU: The Path to Full Employment." Journal of Economic Issues 32, 2 (1998): 547-555.

Mitchell, William and Warren Mosler. "Understanding the Economic Fallacies of the Intergenerational Debate.” Australian Journal of Social Issues 41, 2 (2006): 159-170.

Mitchell, William and Joan Muysken. Full Employment Abandoned: Shifting Sands and Policy Failures. Cheltenham, UK: Edward Elgar, 2008.

Mitchell, William and Martin Watts. "A Comparison of the Macroeconomic Consequences of Basic Income and Job Guarantee Schemes.” Working Paper No. 04-05. Center of Full Employment and Equity, University of Newcastle, 2004. 
—_ "Capacity Constraints and the Job Guarantee.” Working Paper No. 04-13. Center of Full Employment and Equity, University of Newcastle, 2013.

Mosler, Warren. "Full Employment and Price Stability.” Journal of Post Keynesian Economics 20, 2 (1997-1998): 167-182.

Murray, Michael J. and Mathew Forstater, eds. The Job Guarantee: Toward True Full Employment. New York, NY: Palgrave Macmillan, 2013.

Nell, Edward J. and George Argyrous. "Transformational Growth, Endogenous Demand, and a Developmental ELR Program." In The Job Guarantee: Toward True Full Employment, edited by Michael J. Murray and Mathew Forstater, pp. 125-159. New York, NY: Palgrave Macmillan, 2013. Nozick, Robert. Anarchy, State, and Utopia. New York, NY: Basic Books, 1974.

Papadimitriou, Dimitri B. and L. Randall Wray. “Does Social Security Need Saving?” Public Policy Brief, No. 55. Jerome Levy Economics Institute of Bard College, 1999.

Pigeon, Marc-André and L. Randall Wray. "Did the Clinton Rising Tide Raise All Boats? Job Opportunity for the Less Skilled." Public Policy Brief, No. 45. Jerome Levy Economics Institute of Bard College, 1998.

Rawls, John. Political Liberalism. New York, NY: Columbia University Press, 1993.

—. A Theory of Justice. Revised Edition. Cambridge, MA: Harvard University Press, 1999.

Roemer, John. Free to Lose: An Introduction to Marxist Economic Philosophy. London, UK: Radius, 1988.

Ruml, Beardsley. "Taxes for Revenue Are Obsolete.” American Affairs 8, 1 (1946a): 35-39.

—_. "Tax Policies for Prosperity." American Economic Review 36, 2 (1946b): 265- 274. 
Sandel, Michael J. What Money Can't Buy: The Moral Limits of Markets. New York, NY: Farrar, Straus and Giroux, 2012.

Sen, Amartya. Inequality Reexamined. Cambridge, MA: Harvard University Press, 1992.

—. Development as Freedom. New York, NY: Anchor Books, 1999.

Social Security Administration (SSA). Annual Report of the Board of Trustees of the Federal Old and Survivors Insurance and Federal Disability Insurance Trust Funds. Washington, D.C.: U.S. Government Printing Office, 2011.

Staub, Ervin. "Basic Human Needs, Altruism, and Aggression." In The Psychology of Good and Evil, edited by Artuhur G. Miller, pp. 51-84. New York, NY: Guilford Press, 2004.

Tcherneva, Pavlina. "Reorienting Fiscal Policy: A Critical Assessment of Fiscal Fine-Tuning.” Working Paper No. 772. Jerome Levy Economics Institute of Bard College, 2013.

Tcherneva, Pavlina and L. Randall Wray. 'Gender and the Job Guarantee: The Impact of Argentina's Jefes Program on Female Heads of Poor Households.” Working Paper No. 50. Center for Full Employment and Price Stability, 2005

Wray, L. Randall. Understanding Modern Money: The Key to Full Employment and Price Stability. Cheltenham, UK: Edward Elgar, 1998.

—_. "Demand Constraints and Big Government." Working Paper No. 488. Jerome Levy Economics Institute of Bard College, 2007.

- Modern Money Theory: A Primer on Macroeconomics for Sovereign Monetary Systems. New York, NY: Palgrave Macmillan, 2012.

_. "From the State Theory of Money to Modern Money Theory: An Alternative to Economic 
Orthodoxy.” Working Paper No. 792. Jerome Levy Economics Institute of Bard College, 2014.

Wray, L. Randall and Mathew Forstater. "Full Employment and Social Justice." In The Institutionalist

Tradition in Labor Economics, edited by Dell P. Champlin and Janet T. Knoedler, pp. 253-272.

Armonk, NY: M.E. Sharpe, 2004. 